Revista de Lenguas para Fines Específicos

https://ojsspdc.ulpgc.es/ojs/index.php/LFE/index

\title{
Generic Ascription and Didactic Practice in the Latin Riddle of the Exeter Book
}

\author{
Mercedes Salvador Bello ${ }^{1}$ \\ Universidad de Sevilla \\ Facultad de Filología, Calle Palos de la Frontera, s/n, 41004, Sevilla, Spain
}

\section{Article history \\ Paper received: 02 May 2018 Paper received in revised form and accepted for publication: 04 October 2018}

\section{Keywords}

Exeter Book Riddles, Riddle 90, Latin beast poetry, fables, Ecbasis captivi, medieval school practice

\section{Palabras clave}

Adivinanzas del Exeter Book, Adivinanza 90, poesía bestiaria en latín, fábulas, Ecbasis captivi, práctica escolar medieval

\author{
ABSTRACT
}

Riddle 90 constitutes one of the most obscure texts included in the Exeter Book collection. Being fully written in Latin, this piece has so far frustrated a plausible explanation of its puzzling clues to the extent that no convincing answer has been found for it yet. The main aim of this essay however is not to put forward another solution for the long catalogue of proposals that has already been offered by scholars. Instead, I will here argue that the relative lack of viable solutions comes from the fact that this text issued from a reworking of a school beast poem, which was awkwardly adapted to the enigmatic format. A better understanding of this poem can thus be attained if its rhetorical components and imagery are read in the light of beast poetry deriving from classical fables used in the medieval period. This hypothesis can also help explain the overemphatic occurrence of textual elements that are typical of the enigmatic genre. This essay will therefore try to demonstrate that the contents of Riddle 90 are reminiscent of this literary tradition, which developed in the school context of the early medieval period.

\section{RESUMEN}

La Adivinanza 90, única composición en latín incluida en el Exeter Book, es un enigma de por sí. Hasta la fecha no ha sido imposible ofrecer una explicación plausible de sus extrañas pistas, de manera que no se ha encontrado todavía una solución convincente para ella. El objetivo principal de este ensayo no es, sin embargo, añadir una nueva solución más a la larga lista de propuestas que ya ha tenido lugar. La razón principal es que, creo, que este texto no es una adivinanza sino más bien una reelaboración de un poema bestiario medieval, que procede de la práctica escolar. Aunque está bastante claro que algunos de los elementos textuales de la Adivinanza 90 son afines a las características que se observan en otros acertijos, se puede llegar a una mejor comprensión del poema si sus componentes retóricos y sus imágenes se analizan a la luz de la poesía bestiaria medieval, que deriva a su vez de las fábulas clásicas. Este artículo, por tanto, intentará demostrar que los contenidos 
de la Adivinanza 90 son reminiscentes de esta tradición literaria, que se desarrolló en el contexto escolar del periodo medieval temprano.

\section{Introduction: An Unanswearable Monster Riddle}

Riddle 90, the sole Latin composition included in the Exeter Book collection, is an enigma in itself. So far, scholarship has not been able to offer a plausible explanation of its elusive clues and, as a result, no conclusive solution has been found for it yet. My aim here however is not to add one more solution to the extensive list of proposals that has already been put forward. The reason for this is I think this text was not originally a riddle but a reworking from a beast poem, which was modified to make it fit in the enigmatic format. Accordingly, if the rhetorical components and imagery of Riddle 90 are considered in the light of beast poetry deriving from classical fables in the school context of the early medieval period, we will be able to develop a better appreciation of the complex nature of this text.

Without entering into a substantive discussion of the numerous textual irregularities observed in this poem, ${ }^{2}$ a possible editorial reconstruction of Riddle 90 reads as follows:
Mirum mihi uidetur,
lupus ab agno tenetur;
obcubuit agnus rupi
et capit uiscera lupi.
Dum starem et mirarem, uidi gloriam magnam,
duo lupi stantes
et tertium tribulantes;
III pedes habebant,
cum septem oculis uidebant. ${ }^{3}$

(It seems to me wondrous: a wolf has been captured by a lamb; the lamb falls dead on a rock and takes hold of the entrails of the wolf. While I stood still and stared in amazement, I saw a great spectacle: two wolves were standing and afflicting a third one. They had four feet and saw with seven eyes. $)^{4}$

2 For scribal mispellings and grammatical flaws in this text, see Whitbread. See also Krapp and Dobbie (1936: 378).

3 I here offer Krapp and Dobbie's numbering and edition of this poem (1936: 240) with some variations. All other citations from the Exeter Book Riddles in this essay will be from the same edition. With an intent to maintain internal rhyme, I concur with editors who have reordered manuscript "Mirum uidetur mihi." Krapp and Dobbie, however, retain the original order. The tentative addition "rupi," as offered by the latter editors, was contested by Davis and Schlueter (1989: 93, n. 3), who proposed "morti" as a way to provide a metrically acceptable line instead. This idea has most recently been supported by Muir (1994, vol. 2: 680). As with most editions, I here accept mirarem as an emended version of manuscript "misarem," which is however maintained by Krapp and Dobbie even if it seems to be a corrupted form of the former. Following the majority of editors, I have also emended scribal "dui" for "duo".

Unless indicated otherwise, all translations in this essay are mine. 
In its current state in the manuscript, Riddle 90 thus presents readers with several interpretative challenges. First of all, in this Latin poem there is a direct reference to several beasts: three wolves and a lamb. There are other cases in which animals are alluded to in the Exeter Book Riddles, either implicitly as an essential part of the solution or explicitly. If the animal in question is included in the solution, it always speaks in the first person singular, as observed in the series of birds (nos. 7-10), the ox (no. 12), the aurochs (14), the vixen (15), the jay (24) and so forth. Explicit references in the thirdperson singular form are, for example, found in Riddle 24, in which the jay is said to bark like a dog, bleat like a goat, shriek like a goose, scream like a hawk, as well as being capable of imitating the eagle, the kite and the sea-gull. Further animals are mentioned as representative of God's Creation in Riddle 40: the eagle (67), the whale (92), the earthworm (70), the itch-mitch (96) and a mysterious bird alluded to as "pernex" (66). In all these cases, these references are to be interpreted literally, even though some allegorical nuances have been detected by scholars. ${ }^{5}$

When compared to these other pieces from the Exeter Book collection, Riddle 90 clearly stands out, since the animals mentioned in this text seem to be metaphorical references to something else. The lamb has thus been explained by Henry Morley as an allegory of the agnus Dei (the lamb of God). ${ }^{6}$ The idea conveniently dovetails with the apocalyptic leaning observed in Riddle 90 with the allusion to the lamb falling dead ("occubuit agnus," 2) 7 and the seven eyes ("cum septem oculis," 5). ${ }^{8}$ However, in Riddle 90 the seven eyes clearly refer to the wolves, not the lamb. Furthermore, Morley's explanation that the three wolves represent Christ and the crucified thieves does not seem to be viable.

On the other hand, the figure of the wolf has been interpreted as a clue on the author's name, which has been taken to be some form of Cynewulf. ${ }^{9}$ The four feet might be a punning expression of some kind ${ }^{10}$ since it could literally allude to the four legs of a wolf but also to the average size of this animal (four feet). ${ }^{11}$ Taking the clues beyond the literal plane, the seven eyes could rather be a veiled reference to the Pleiades, a cluster of seven stars. ${ }^{12}$ Following this train of thought, this image may be connected

5 See, for example, the allegorical implications observed in Exeter Riddle 9 (cuckoo) in Neville (2007: 436) and Salvador-Bello (2015: 309-10).

$6 \quad$ Morley (1888: 225).

7 Note that "occubuit" in Riddle 90 (2)—from occubo, "to lie in a place; to rest, repose in the grave"-also bears connotations of death. Unless indicated otherwise, definitions of Latin terms in this essay are from Lewis and Short (1891, repr. 1998). For a more detailed discussion of Riddle 90 textual peculiarities, see Salvador-Bello (2018: 109-10).

8 Revelation (5:6): "I saw a Lamb standing, as though it had been slain, with seven horns and with seven eyes, which are the seven spirits of God sent out into all the earth." This citation and all further quotations from the Bible in this essay are from the edition by May and Metzger (1977).

9 Dietrich (1865: 250).

10 For several solutions involving further wordplay, see Williamson (1977: 384-85).

11 I owe this point to Joaquín Gutiérrez Calderón. A further possible use of the term pes with a similar punning intent is offered in Symphosius's Enigma 93 (gouty soldier, 2). See Leary (2014: 231-32). Interestingly, Symphosius's Riddles 33 (wolf) and 34 (fox) seem to be linked on an etymological basis, since both lupus and vulpes are associated with the Latin term pes (i.e., foot) in Isidore's Etymologiae XII.ii.23 and XII.ii.29, respectively (Leary: 2014: 125 and 127).

12 Aldhelm's Enigma 8 precisely describes the Pleiades as a cluster of seven stars ("septena cohors," 2). 
to the Ursa Major or Plough, whose seven brightest stars were equally recognizable in the Middle Ages. ${ }^{13}$ It is also worth noting that there is a constellation called Lupus, known from ancient times. ${ }^{14}$ In short, all these tentative solutions for Exeter Riddle 90 are no doubt attractive in their own way. However, none of them offers an entirely satisfactory explanation of all the poem's clues.

If we now pay attention to the formal features and the contents of this text, we will see that there are several components in this poem that evidently relate it to the enigmatic genre. To begin with, one of these elements is the allusion to an incongrous number of body parts: "IIII pedes habebant cum septem oculis uidebant" (5). The reference to the four feet seems to be consonant with the fact that wolves are quadrupeds but common sense tells us that eyes should equally come in pairs. When an illogical numerical clue of this kind comes up in riddles, there is an apparent contradiction that needs to be solved. This pattern is famously exemplified with the Sphinx's enigma on man. A first version of this well-known puzzle is included in Book XIV of the Greek Anthology, whose earliest materials date from the seventh century BC:

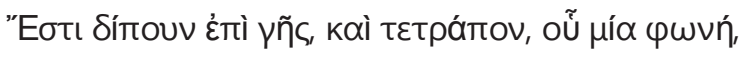

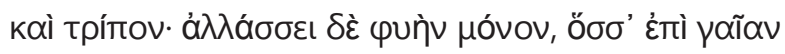

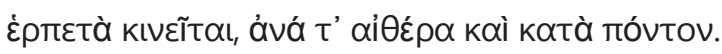

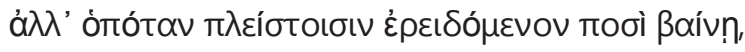

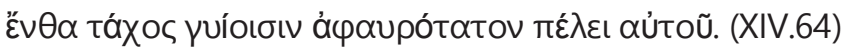

("There is on earth a two-footed, and four-footed, and three-footed, whose name is one, and it changes its nature alone of all creatures that move creeping on earth or in the air and sea. But when it moves supported on most feet, the swiftness of its legs is at its weakest.") $)^{15}$

The monster riddle, as this sub-type is usually referred to by scholars, is therefore ancient and has been developed by enigmatists of different periods.

Clues with an incongrous number of body limbs occur, for example, in Symphosius's Enigma 94, which depicts a soldier as a six-footed creature ("sex qui pedes habui," 2). ${ }^{16}$ The enigma is solved as soon as we understand that the clue alludes to the man's two feet plus the four legs of his horse. A further illustration of the monster riddle is Symphosius's famous Enigma 95 on the one-eyed garlic seller: "Unus inest oculus, capitum sed milia multa" (2) [one eye but many thousand heads are here]. The Old English version (no. 86) elaborates on the terser Latin model as follows:

13 I thank Joaquín Gutiérrez Calderón for this interesting suggestion.

14 Leary (2014: 125) similarly suspects that lupus in Symphosius's Enigma 33 might be suggestive of a constellation, even if in this case the clues do not overtly allude to this. In fact, some of the clues describing quadrupeds in Symphosius's zoological sequence offered in Symphosius's Enigmata explicitly allude to both the living animal and the zodiac sign as, for example, in Riddles 32 (3) and 35 (2), solved respectively as taurus (bull) and capra (goat). The same holds true for Aldhelm's Enigmata 71 and 86, in which the respective title-solutions piscis and aries jointly involve the animal and the constellation.

15 Text and translation cited from Paton (1979: 59).

16 As with all the Latin riddles cited in this essay, I use Glorie's edition (1968, vols 133 and 133A). 


\begin{abstract}
Wiht cwom gongan pær weras sæton
monige on mæðle, mode snottre;

hæfde an eage ond earan twa,

ond II fet, XII hund heafda,

hrycg ond wombe ond honda twa,

earmas ond eaxle, anne sweoran

ond sidan twa. Saga hwæt ic hatte.

(A creature came walking where many men, wise in spirit, were sitting in company; it had one eye and two ears and two feet, and twelve hundred heads, a back and a belly and two hands, arms and shoulders, one neck, and two sides. Say what I am called.)
\end{abstract}

The description of the creature as having a normal amount of limbs and body parts makes perfect sense. Yet the monstrous condition of the beast is implied by the reference to its having just one eye, as if suggesting a cyclopean nature, and hundreds of heads as if it were a hydra. The shocking answer is "a one-eyed seller of garlic" if the anomalous number of body parts is interpreted correctly by discriminating what is literal from what is metaphorical. The monster-riddle pattern was also wellknown to Aldhelm, whose Enigmata 84 (pregnant sow) and 90 (woman giving birth to twins) are also good illustrations of it. ${ }^{17}$

Given that monster riddles were popular in both Latin and vernacular tradition, it is therefore reasonable to conjecture that by including Riddle 90 in the Exeter Book collection, the compilers aimed at providing a further example of this well-known sub-type. With such a high degree of difficulty, it is perhaps unsurprising to find this text copied in the last sequence of the manuscript. Furthermore, its close occurrence to the other complex numerical puzzle, Riddle 86 (the one-eyed seller of garlic), makes this inference stronger. ${ }^{18}$ However, if Exeter Riddle 90 is an enigma entailing the playful allusion to an illogical number of body parts, its solution should be as hard to find as those by Symphosius and Aldhelm. The reference to the seven eyes in Riddle 90 may have some similar metaphorical implications that we are missing. As pointed out by Jonathan Wilcox (1996: 183) with regard to Exeter Riddle 86, this text may contain "an arbitrary trick, which makes the solution to the riddle unguessable except by those with privileged information." As we have no analogous version in the Latin collections and no title-solution for Exeter Riddle 90, we will probably never be able to offer a plausible interpretation of its cryptic clues. Seen in this light, the solving of Exeter Riddle 90 escapes us because we do not possess that "privileged information," using Wilcox's words, to grasp the particular "trick," which might have only been intelligible to contemporary readers. Several scholars, most recently John

17 As Stork (1990: 33) pointed out, these two compositions seem to have been designed to practise Latin numerals, an idea that might be extended to any riddle in which the enumeration of body parts is involved.

18 It was common practice to leave the most difficult riddles at the end of collections. This is, for example, observed in Symphosius's Enigmata in which the monster riddles-notably nos. 92, 93 and 94-occur at the close of the collection. 
D. Niles (2006: 144), have consequently labeled the riddle as "uncertain." Accordingly I will concentrate on the study of this text's contents and formal aspects.

\section{A Riddle that was not a Riddle}

A further element relating Riddle 90 to the enigmatic genre is the occurrence of several formulaic expressions. Indeed, the initial line "Mirum mihi uidetur" and "uidi gloriam magnam" (3) clearly relate to traditional riddlic formulas conveyed by means of verbs such as uideo or cerno in Latin enigmata; these in turn give way to ic (ge)-seah phrases typically offered in many of the Exeter Book Riddles. These utterances are frequently used in riddles in which apparent reality is challenged by logic. This is observed, for example, in Symphosius's Enigma 76 (flint): "Semper intus, sed raro cernitur ignis" (1) [Fire is always inside but you rarely see it]. The same verb is used by Aldhelm in Enigma 2 to describe the mysterious nature of wind: "Cernere me nulli possunt nec prendere palmis" (1) [No one can see me nor seize me with his hands (literally, palms)]. A similar employment of the verb uideo is found in Tatwine's Enigma 4 on man: "Hec mea materię substantia bina creata est. / Sed grauis una uidetur, quae tamen ipsa peribit" (1-2) [The substance of my matter was created in two parts. One (of them) is seen as heavy, but this will however die]. In Aldhelm's Enigma 40 (pepper) the verb uideo is similarly used: "sed me subnixum nulla uirtute uidebis, / uiscera ni fuerint nitidis quassata medullis" (5-6) [But you will not see me relying on any power if the entrails with my bright marrow have not been crushed]. In other words, the releasing of the properties of pepper paradoxically depends on the destruction of this vegetable. In all these cases the poet makes use of verbs of visual perception to express a contradictory fact that needs to be understood by the reader to come to the right solution.

In Exeter Riddle 90, the presence of the adjective "mirum" in line 1 also associates this composition with elements that usually appear in combination with this type of formula in Latin enigmata. ${ }^{19}$ The phrase "mirum dictu" (it is wonderful to say), for example, occurs in Aldhelm's description of the floursieve in Enigma 67 (9). It was evidently known to Tatwine who uses it in Enigmata 11 (4), 14 (3) and 27 (1), ${ }^{20}$ in the latter as "mirabile dictu," a locution that was possibly taken from Vergil's Aeneid IV.182. In turn, the peacock in Aldhelm's Enigma 14 is "admired in the world" ("mirandus in orbe," 1). ${ }^{21}$ A similar use of this formula is observed in the opening query of Alcuin's Disputatio Pippini cum Albino, which is solved as "a reflection in the water":

P.[ippinus]. “Quid est mirum?—A[lbinus]. Nuper uidi hominem stantem, molientem, ambulantem, qui numquam fuit.

P. What is a wonder? -A. Recently I saw a person standing, moving, walking, who never was. ${ }^{22}$

The adjective "mirum" and the verb "uidi" thus effectively combine to communicate the idea of utter amazement that is expected on the part of the solver when thinking of the peculiar nature of the

19 mirus, meaning "wonderful, marvellous, astonishing, extraordinary." For a recent study of these formulas, which are particularly abundant in Anglo-Saxon riddles, see Ramey (2018).

20 These riddles are solved as needle, charity and tongs, respectively.

21 From miro (see further in this essay).

22 Text and translation from Bayless (2002: 174, no. 86). 
phenomenon that is described. Interestingly, the use of the present participle "stantem" recalls the reference to the two standing wolves ("duo lupi stantes," 4) in Riddle 90. This pattern (uidi + noun + present participle) is also observed in Pseudo-Bede's Enigma 198, which is solved by Frederick Tupper (1905: 565) as the quill writing holy words on parchment: "Uidi uirginem flentem et murmurantem: uiae eius sunt semitae uitae" ("I saw a girl weeping and muttering; her ways are the paths of life"). ${ }^{23}$ Seen in this light, Riddle 90 clearly imitates conventional uidi-formulas similar to those observed in Latin enigmata and riddling dialogues, the latter texts being specifically designed for school practice. ${ }^{24}$

Nevertheless, the overemphatic presence of these formulaic components in Riddle 90 is at best suspicious. Indeed, the verb uideo occurs twice, once as "uidetur" (1) and then as "uidi" (3). Additionally, the pleonastic reference to wolves looking with seven eyes ("cum septem oculis uidebant," 5) brings about a third occurrence of this verb. As if that was not enough, the poet makes further use of a verb related to the semantic field of sight with "mirarem" (3)-from Latin miro, meaning "to wonder or marvel at, to be astonished or amazed at a thing; to admire." The joint presence of "mirum," "mirarem," and later the phrase "gloriam magnam" (3) is equally insistent, since these three elements are meant to convey the idea of wonder. ${ }^{25}$ It looks as if the poet was trying to gather formulaic expressions to ensure the text would be categorized as a riddle. This unnatural accumulation of conventional phrases in Riddle 90 may betray a reworking of a text that was originally not an enigma.

This hypothesis finds support in further instances in which other authors incorporate passages from non-riddlic works into their enigmata. This literary recycling is, for example, best exemplified with Aldhelm's Enigma 97, in which a citation from Virgil's Aeneid (IV.177, 181-4) is integrated verbatim as lines 11-16 of this poem. It has also been pointed out that some of Aldhelm's Enigmata heavily rely on the descriptions offered in Isidore's Etymologiae. ${ }^{26}$ An even more remarkable case is Eusebius's zoological section in which some of the riddles practically constitute versified paraphrases of the corresponding excerpts from Isidore's Etymologiae. ${ }^{27}$

If we turn our attention back to the clues of Riddle 90, there are interesting semantic nuances that are worth taking into consideration, since they support my contention that this text stems from a nonriddlic work. The lamb, which is usually portrayed as one of the weakest animals in literary tradition, is however described in Riddle 90 as defeating a wolf. Indeed, the passive form of the verb ("tenetur") and the agent ("ab agno") in line 1 leave no room for doubt it is the lamb that has captured the wolf,

23 Text and translation from Bayless and Lapidge (1998: 144-45). A similar riddle triad offering this pattern is found in St Gall, Stiftsbibliothek, Cod. Sang. 196 (Daly and Suchier 1939: 144, n. 91). For further information, see Bayless and Lapidge (1998: 245 and Salvador-Bello 2015: 49).

24 For a thorough analysis of this text in the school context of the late Anglo-Saxon period, see Salvador-Bello (2018).

25 Cf. Aldhelm's prose De virginitate: "uersicolor pauonis gloria" (the multi-colored display of the peacock). Latin gloria with the specific meaning "splendour, magnificence" as found in Aldhelm's passage thus parallels the use of this term in that sense in Riddle 90. The definition is from the Dictionary of Medieval Latin from British Sources (1975-2018). This citation from Aldhelm's De uirginitate is precisely provided by the editors to illustrate this meaning (no. 2) of gloria in this dictionary. The wondrous nature of the squid is described by Aldhelm's Enigma 16 with a similar term: "Nunc cernenda placent nostrae spectacula uitae" (1) (Onlookers are now pleased with the spectacle of my life].

26 See Stork [1990: 67].

27 See Salvador-Bello (2012)

Revista de Lenguas para Fines Específicos 24.2 ISSN: 2340-8561 
an idea which is against common sense. If compared to Symphosius's Enigma 33 (lupus), the wolf here plays the traditional role of the predator at the top of the food chain: "Dentibus insanis ego sum qui uinco bidentes" (1). ${ }^{28}$ The riddle thus metonymically alludes to the ravenous teeth ("Dentibus insanis") of the wolf conquering the two-teethed ones-i.e, the lambs ("bidentes"). Furthermore, the verb "uinco" parallels "tenetur," which can equally have connotations of victory over an adversary in Riddle 90.29

The reference to the two wolves causing suffering to a third wolf in Riddle 90 is most intriguing because it implies violence among members of the same species, an idea that is not observed in either Latin or vernacular riddling tradition. ${ }^{30}$ In the Exeter Book riddles collection, the predator is normally another animal, as is the case of the hound from which the courageous vixen protects her offspring in Riddle $15 .^{31}$ The proverbial enmity of the oyster and the crab seems to lie at the heart of the juxtaposition of Riddles 77 and $78,{ }^{32}$ just as it is in the following passage from Aldhelm's Enigma 37: "ostrea quem metuit duris perterrita saxis" (6) [Frightened by the hard stones (that I throw at it), the oyster dreads me]. ${ }^{33}$

Also in Anglo-Saxon enigmatic tradition, animals and plants are most typically viewed as objects providing food, clothing and useful implements to human beings. In these cases, the riddlic object is usually characterized as a victim of people's greed. The act of opening the oyster with the point of a knife ("seaxes orde," 6) and the subsequent reference to eating it uncooked ("unsodene," 8) makes the man ("monna sum," 4) of Exeter Riddle 77 rank with uncivilized cannibals, as subtly suggested by the clues. ${ }^{34}$ The allusion to a knife depriving the hart of its antlers similarly underscores this conventional image of man's predatory role in Exeter Riddles 88 (29-30) and 93 (17-20), both solved as inkhorn. In Aldhelm's Enigma 60, the clues dwell on the description of how the unicorn is vainly pursued by the hunter and his hound but is, however, defeated by a defenseless maiden ("et uirgine uincor inermi," 7). All in all, the pattern is usually that of hunter versus prey, involving animals of different type, or human versus animal.

With its allusion to the two wolves oppressing a third one, Riddle 90 therefore stands out from the other companion pieces of the Exeter collection and from Anglo-Latin enigmata. For this reason, scholars have tended to provide an allegorical explanation of the zoological imagery found in this text.

28 The form "bidentes," as found in Bergamin (2005: 26) seems to me preferable to "uidentes," as offered by Glorie (1968, vol. 133A: 654). As explained by Leary (2014: 125-26), this epithet refers to "young sheep," since "ruminants acquire their first two permanent teeth after two years and these stand out prominently from the surviving milk teeth."

29 teneo (2a): "With the accessory idea of possession, to hold, i. e. to be master of, have in one's power, possess, etc."

30 Dictionary of Medieval Latin (1975-2018: s.v. tribulare, "to oppress, afflict"). As a present participle acting as an adjective (sense b), "oppressive, that causes suffering."

31 There is no consensus as to which hunting animal is implied by "wælhwelpes" (23), most likely a hound, although the term may also refer to a wolf. See Williamson (1977: 177).

32 See Salvador-Bello (2004).

33 Aldhelm's text clearly alludes to the traditional belief that the crab could use a pebble to open the tight valves of the oyster. See also Salvador-Bello (2015: 108-09), for a discussion of these two animals as an antagonistic pair in Isidore's Etymologiae (XII.vi.51-52).

34 On the moralistic overtones of Riddle 77, see Salvador-Bello (2004: 402). 
However, the clues of Riddle 90 clearly indulge in the absurd, endowing the poem with a nonsensical flavour that is not normally found in enigmatic pieces. This marked idiosyncrasy suggests this poem was originally something different from a riddle, an idea that I intend to develop in the following section of this essay.

\section{Riddle 90 and Beast Poetry}

Leaving aside the elements that associate Riddle 90 with enigmatic tradition, the imagery offered in this text seems also to be related to medieval beast literature. If we accept this to be so, we should then be able to track its sources. As explained by Jan Ziolkowski, references to animals in medieval literature are mainly to be sought in the Physiologus, the Bible and fables. ${ }^{35}$ Michael Lapidge and other scholars have pointed out that Aldhelm might have had a copy of the Physiologus ${ }^{36}$ at hand when composing his Enigmata. ${ }^{37}$ Indeed, some of the topics of this collection-for example, salamander, ant-lion, magnet, night-raven, and lion-are found in the Physiologus. We should however rule out the Physiologus as a possible source for the zoological imagery offered in Exeter Riddle 90, since neither the wolf nor the lamb are dealt with in the early versions of this text that have come down to us.

By contrast, the Bible is a well-known source of zoological lore in which both the wolf and the lamb figure prominently. The polarization of these two animals as the epitome of meekness, in the case of the lamb and rapaciousness, in the case of the wolf, is found in several parables of the New Testament. Notably, in John 10.11-13, Christ is characterized as a shepherd taking care of his flock of sheep, protecting them against the lurking wolf:

I am the good shepherd. The good shepherd lays down his life for the sheep. He who is a hireling and not the shepherd, whose own the sheep are not, sees the wolf coming and leaves the sheep and flees; and the wolf snatches them and scatters them. He flies because he is a hireling and cares nothing for the sheep. ${ }^{38}$

The biblical metaphor is ubiquitously employed in medieval literature to compare Christ's role with the pastoral duties of priests and bishops. The motif is, for instance, central to Lyric 8 from the Exeter Book Advent sequence. ${ }^{39}$

35 Ziolkowski (1993: 2).

36 Originally in Greek, the Physiologus was probably produced in Alexandria in the second century and was later translated into Latin. For further information on this work, see Curley (1979: ix-xxxiii). An edition of the Physiologus (versio Y) is found in Carmody (1941).

37 Lapidge and Rosier (1995: 247) state that "perhaps an early recension of the Latin Physiologus" might have been available as a literary source for Aldhelm's Enigmata. For further information on the Physiologus and Aldhelm's Enigmata, see Salvador-Bello (2014: 215-16).

38 Apart from this, the joint reference to the wolf and the lamb occurs, for instance, in two passages from the Old Testament, notably Isaiah 11:6 and 65:25. For further information, see Ziolkowski (1993: 204-05).

39 See also O'Camb (2016) for an analysis of the reference to wolves in the Exeter Book Maxims. 
The paradoxical nature of the imagery observed in Riddle 90 is, however, distant from biblical imagery and should rather be connected with fables or beast poems. ${ }^{40}$ Indeed, the lamb playing the role of the hunter and the standing wolves oppressing a third clearly align with the anthropomorphism that is specific of these two literary genres. It has generally been assumed that collections of fables became popular in the eleventh century, when they started to be anthologized in manuscripts. That is the case of Oxford, Bodleian Library Rawlinson, G. 111, a codex containing some forty-six fables in Latin hexameters. ${ }^{41} \mathrm{~A}$ further piece of evidence demonstrating that these texts were known in the late Anglo-Saxon period is the presence of eight illustrations of fables accompanying the pictures of Harold's sea journey to Normandy in the Bayeux Tapestry. Interestingly for this essay, in four of these fables the wolf figures prominently. ${ }^{42}$ As scholars consider that the embroiderings are the product of an Anglo-Saxon working team, ${ }^{43}$ it is fair to conclude with Gail Ivy Berlin (2003: 195) that the English readership was well acquainted with fables "either shortly before or shortly after the Conquest." ${ }^{44}$

Evidence of the knowledge of fables in pre-Conquest England is, however, more difficult to demonstrate. Nevertheless, as both riddles and fables have in common the fact that they offer personified animals, it is quite logical to suspect that an interaction of the two genres might have taken place well before the eleventh century. In fact, many of the animals of the zoological sequence from Symphosius's Enigmata, whose earliest version appears in the Salmasian codex (c. 800), ${ }^{45}$ have a role in the stories contained in Romulus, the most popular collection of fables of the Middle Ages. ${ }^{46}$ It may therefore be tentatively inferred that the combined study of fables and Symphosius's Enigmata, which has been preserved in several English codices, ${ }^{47}$ might have taken place in medieval schools.

On the other hand, the portrayal of some of the animals found in Symphosius's Enigmata betrays some common traits with fable characters. As pointed out by Georg Thiele (1010: cxxx), Enigma 23, for example, offers significant parallelisms with passages from Phaedrus's Fables and Romulus. Additionally, the juxtaposition of the wolf and the fox as offered with Symphosius's Riddles 33 and 34 is explained by Ziolkowski (1993: 42) on the grounds of "their enmity from either fables or folktales." The same holds true for Symphosius's Riddles 22 (ant) and 23 (fly), where the two creatures convey positive and negative examples, respectively, in a way that recalls their role in these works. This

40 For the distinction between fables and beast poems, see Ziolkowski (1993: 2-3). Basically, a beast poem is an animal fiction lacking "the moral essential to beast fable" (idem, 3).

41 As extant in this manuscript, these fables have been edited by Hervieux (1884, vol. 2: 653-713).

42 Notably, in order of appearance in the tapestry: "The Wolf and the Lamb," "The Wolf and the Crane," "The Wolf Reigning," and "The Goat and the Wolf." For the allusive function of these fables in the border pictures of the Bayeux Tapestry, see further in Berlin (2003).

43 As concluded by Berlin (2003: 192), "The master designer, scribe (if indeed a different person from the master designer), and needlewomen [. . .] are likely to have been Anglo-Saxon."

44 Berlin (2003: 195).

45 The name of the manuscript (Paris, Bibliothèque Nationale, Lat. 10318) derives from Claude de Saumaise, who owned it between 1609 and 1620. A thoroughgoing introduction to its history and contents is found in Socas Gavilán (2011: 7-18).

46 That is the case of the wolf, the fox, the crane, the mule, the goat, the ant, the fly, the mouse, the frog, the bull, and the tortoise. An edition of the Romulus is found in Thiele (1910: 2-306).

$47 \quad$ See Salvador-Bello (2015: 134-35). 
antagonistic relationship is also textually supported. Riddle 22 thus opens by stating the ant is "prouida" (1, provident, prudent) whereas Enigma 23 offers the adjective "improba" (1, immoderate, greedy) for the fly. ${ }^{48}$

"De lupo et agno" ("The Wolf and the Lamb"), a fable from Phaedrus's collection, would probably be one of the texts used by medieval students of Latin, as it still is nowadays. Usually understood as an illustration of the abuse of power, the eleventh-century version of this fable by Ademar of Chabannes is as follows:

Lupus et Agnus ad riuum uenerunt. Superior Lupus, longe inferior Agnus. Tunc fauce improba latro incitatus iurgio dixit: Cur turbulentam fecisti mihi aquam? Laniger: Qui fieri potest, dum a te liquor decurrens ad meum os uenit? L[upus]: Ante hos sex menses maledixisti mihi. R[es]p[ondit]: Non eram natus. L[upus]: Pater tuus maledixit mihi. Et ita correptum lacerat iniuste.

Qui fictis causis innocentes opprimunt.

("A wolf and a lamb came to the river. Upstream the wolf, far away downstream the lamb. Then, to begin a quarrel, the bandit with insatiable gullet said: Why do you make a disturbance of my water? The wool-clad one: How can that be said, when the running water comes from you to me? The wolf: Before this, six months ago you slandered me. Replies the lamb: I was not born then. The wolf: Your father slandered me. And he unjustly attacked and tore him to pieces right there.

In this way, the innocent are oppressed by false claims.") ${ }^{49}$

The fable offers the story of the innocent lamb that was assaulted by the mighty wolf, thus exemplifying the usual hierarchy in the natural world order. Interestingly, the wolf is here characterized by its "greedy throat" ("fauce improba"), a feature shared with the fly in Symphosius's Enigma 23.50

An example of the ways the traditional uppermost position of the wolf could be challenged in medieval beast poetry is offered in the Ecbasis captivi-an anonymous mid-eleventh century allegorical poem probably deriving from fables. ${ }^{51}$ This work's main plot deals with a calf that has been captured by a wolf at Easter. Contrary to its proverbial voraciousness, the wolf does not eat the calf because he has a dream, in which he is warned not to do so. The wolf is eventually tricked by the other animals into coming out of the lair and is finally killed by a bull. The calf thus manages to escape and survive. The Ecbasis captivi is the earliest text in which this seemingly absurd subversion of the zoological order takes place. The author of Riddle 90 most likely used an earlier beast poem of this kind to offer a condensed version in enigmatic format.

For a similar appreciation of these two riddles as an antithetical pair, see Ziolkowski (1993: 41-2) and Pizarro Sánchez (1999: 242).

Text and translation from Weever (2010: 50).

50 The last part of line 1 of Symphosius's Enigma 23 reads: "quid enim gula turpe ueretur?" (for what ugly thing should my throat fear?). Like the wolf, the fly is thus similarly characterized by greed and immoderate appetite.

51 The full title is Ecbasis cuiusdam captivi per tropologiam (The flight of the captive through allegorical exposition). An edition of this text is found in Zeydel (1964). 
If we pay attention to the contents of Riddle 90, we will be able to see that some of the images are close to the typical components of beast poetry. Being the traditional embodiment of defenselessness, the lamb is presented in Riddle 90 as virtually conquering the wolf: "lupus ab agno tenetur" (1). Later on, the lamb takes hold of the entrails of the wolf ("et capit uiscera lupi," 2), again an action that does not fit the typical gentle characterization of this animal. These lines therefore clearly play on a reversal of the traditional roles of the wolf and the lamb as predator and prey, respectively, offering a characteristic topsy-turviness that is typical of beast poems such as the Ecbasis captivi. Furthermore, the reference to the two standing wolves troubling a third one is also reminiscent of beast poetry, in which animals are capable of actions that are normally performed by humans. This anthropomorphism is no doubt a key feature of beast poetry. ${ }^{52}$ We should therefore not preclude the possibility that Exeter Riddle 90 could be an illustration of the transfer of elements from medieval beast poetry into the enigmatic genre.

\section{Conclusions}

After all I have discussed here, I am afraid Riddle 90 will still be the most challenging enigma of the Exeter Book. However, with this study a good number of significant compositional aspects of this text have been brought to light for the first time. As this essay has demonstrated, Riddle 90 displays a significant amount of formulaic ingredients that suggest this poem was originally non-enigmatic. Furthermore, the inversion of the traditional roles of the wolf and the lamb as predator and prey points to a lost Latin beast poem that was probably used as the basis for the Exeter piece. The crude errors and faulty prosody of Riddle 90 similarly evince this text is the work of an incompetent poet, most possibly a student, who was trying to adjust an excerpt from a school beast poem to the enigmatic framework. This would also explain the unusual accumulation of riddlic formulas as illustrated with the repetitive use of the verb uideo and the emphatic reference to a wondrous prodigy.

The original text was therefore reshaped to function as a numerical puzzle entailing first-rate difficulty. As such, it is placed at the end of the Exeter collection and is clearly as hard to solve as Symphosius's enigma on the one-eyed garlic seller, a solution we know thanks only to the explicit reference to it in some manuscripts. It is also on account of this analogue we know the answer to Exeter Riddle 86. However, we do not have any other versions of Riddle 90; nor are there any analogues. Owing to this lacuna, it will be impossible to unravel Riddle 90's cryptic clues unless a parallel with a title-solution or a glossed answer is found in the future. Unfortunately for us, both circumstances cannot be envisaged because the text looks like a school impromptu piece. As such, Riddle 90 probably had a solution that was only locally known. This case can compare to an anonymous Latin verse enigma alluding to a particular drinking practice in the monastery at Abingdon. ${ }^{53} \mathrm{~A}$ convincing solution was proposed by David W. Porter, who pointed to a passage from the Chronicle of Abingdon (thirteenth century), in which this special allowance of beer, locally known as "Æthelwold's bowl," is mentioned. Unless a similar finding is made for Exeter Riddle 90, it will probably remain an unsolved enigma forever.

Ziolkowski (1993: 6).

53 This riddle survives in a flyleaf (1r) of Antwerp, Plantin-Moretus Museum M.16.2. 


\section{About the author}

Mercedes Salvador-Bello is Associate Professor of English at the Universidad de Sevilla. Her research interests include Anglo-Saxon and Insular Latin literature with a particular focus on the Exeter Book, the Old English Riddles and Latin enigmata.

\section{References}

Bayless, M. (2002). Alcuin's Disputatio Pippini and the Early Medieval Riddle Tradition. In Halsall, G. (Ed.). Humour, History and Politics in Late Antiquity and the Early Middle Ages (pp. 157-78). Cambridge: Cambridge University Press.

Bayless, M. \& Lapidge, M. (eds). (1998). Collectanea Pseudo-Bedae. Dublin: Institute for Advanced Studies.

Bergamin, M. (ed. \& trans.). (2005). Aenigmata Symposii: la fondazione dell'enigmistica come genere poetico. Florence: SISMEL-Edizioni del Galluzzo.

Berlin, G. I. (2003). The Fables of the Bayeux Tapestry: An Anglo-Saxon Perspective. In Mark C. Amodio, M.C. \& O'Brien O'Keeffe, K. (Eds.), Unlocking the Wordhord: Anglo-Saxon Studies in Memory of Edward B. Irving, Jr. (pp. 191-216). Toronto: $\mathrm{U}$ of Toronto P.

Carmody, F. J., ed. (1941). Physiologus Latinus Versio Y. University of California Publications in Classical Philology, 12, 95134.

Curley, M. J., trans. (1979). Physiologus. Austin: U of Texas P, 1979.

Daly, L. W. \& Suchier, W. (eds.). (1939). Altercatio Hadriani Augusti et Epicteti Philosophi. Urbana, IL: U of Illinois P.

Davis, P. \& Schlueter, M. 1989. The Latin Riddle of the Exeter Book. Archiv für das Studium der neuren Sprachen und Literaturen, 226, 92-99.

Dictionary of Medieval Latin from British Sources. (1975-2018). Oxford: British Academy. [Accessed online on April 11, 2018].

Dietrich, F. (1865). Die Räthsel des Exeterbuchs: Verfasser; Weitere Lösungen. Zeitschrift für deutsches Altertum und deutsche Literatur 12: 232-52.

Ehwald, R. (ed.). (1919). Aldhelmi opera. Monumenta Germaniae Historica, Auctores Antiquissimi. Vol. 15. Berlin: Weidmann. Glorie, F., (ed.). (1968). Corpus Christianorum Series Latina. Vols. 133 and 133A. Turnhout: Brepols.

Hervieux, L. (ed.). (1884). Les fabulistes latins. Vol. 2. Paris.

Krapp, G. P. \& Kirk Dobbie, E.V.K. (eds.). (1936). The Exeter Book. Anglo-Saxon Poetic Records. Vol. 3. New York: Columbia UP.

Lapidge, M. \& Rosier, J. L., (eds. \& transs.). (1985). Aldhelm: The Poetic Works. Cambridge: Cambridge UP.

Leary, T. J. (ed. \& trans.). (2014). Symphosius: The Aenigmata. An Introduction, Text and Commentary. London: Bloomsbury Academic.

Lewis, C. T. \& Short, C. (1891, repr. 1998). A New Latin Dictionary. Oxford: Clarendon P.

May, H. G. \& Metzger, B.M. (eds.). (1977). The New Oxford Annotated Bible with the Apocrypha. New York: Oxford UP.

Morley, H. (1888). English Writers. Vol. 2. London.

Muir, B. J. (ed.). (1994). The Exeter Anthology of Old English Poetry. 2 vols. Exeter: U of Exeter P. 
Neville, J. 2007. Fostering the Cuckoo: Exeter Book Riddle 9. The Review of English Studies, 58 (236), 431-46.

Niles, J. D. (2006). Old English Enigmatic Poems and the Play of the Texts. Turnhout: Brepols.

Paton, W. R. (ed. \& trans.). (1979). The Greek Anthology, Vol. 5. Cambridge, MA: Harvard UP.

Pizarro Sánchez, J. (1999). Estructura y tipología de los Aenigmata Symphosii. Cuadernos De Filología Clásica. Estudios Latinos, 16, 239-46.

Porter, D. W. (1996). Ætethelwold's Bowl and The Chronicle of Abingdon. Neuphilologische Mitteilungen, 97, 163-7.

Ramey, P. (2018). Crafting Strangeness: Wonder Terminology in the Exeter Book Riddles and the Anglo-Latin Enigmata. The Review of English Studies, 69 (289), 201-15.

Salvador-Bello, M. (2018). Exeter Book Riddle 90 under a New Light: A School Drill in Hisperic Robes. Neophilologus, 102(1), 107-123.

Salvador-Bello, M. (2015). Isidorean perceptions of order: The Exeter Book riddles and medieval Latin enigmata. Morgantown: West Virginia UP.

Salvador-Bello, M. (2014). Allegorizing and Moralizing Zoology in Aldhelm's Enigmata. Revista canaria de estudios ingleses, 68, 209-18.

Salvador-Bello, M. (2012). Clean and Unclean Animals: Isidore's Book XII from the Etymologiae and the Structure of Eusebius's Zoological Riddles. English Studies, 93(5), 572-82.

Salvador-Bello, M. (2004). The Oyster and the Crab: A Riddle Duo (Nos. 77 and 78) in the Exeter Book. Modern Philology 101(3), 400-19.

Socas Gavilán, F. (2011). Antología Latina, Repertorio de poemas extraídos de códices y libros impresos. Madrid: Gredos.

Stork, N.P. (1990). Through a Gloss Darkly: Aldhelm's Riddles in the British Library MS Royal 12.C.xxiii. Toronto: Pontifical Institute of Mediaeval Studies.

Thiele, G. (1910). Der Lateinische Äsop des Romulus und die Prosa-Fassungen des Phädrus. Heidelberg: Carl Winter.

Tupper, F. Jr. (1905). Riddles of the Bede Tradition. The 'Flores' of Pseudo-Bede. Modern Philology, 2(4), 561-72.

Weever, J. de. (2010). Aesop and the Imprint of Medieval Thought: A Study of Six Fables as Translated at the End of the Middle Ages. London: Mcfarland.

Wilcox, J. (1996). Mock-Riddles in Old English: Exeter Riddles 86 and 19. Studies in Philology, 93, 180-87.

Whitbread, L. (1946). The Latin Riddle in the Exeter Book. Notes \& Queries, 190, 156-58.

Williamson, C. (ed.). (1977). The Old English Riddles of The Exeter Book. Chapel Hill: U of North Carolina P.

Zeydel. E. H. (ed.). (1964). Ecbasis cuiusdam captivi per tropologiam. Chapel Hill: U of North Carolina P.

Ziolkowski, J. M. (1993). Talking Animals: Medieval Latin Beast Poetry, 750-1150. Philadelphia: U of Pennsylvania P. 